LA--10723-MS

DE86 012693
LA-10723-MS

UC-66b

Issued: May 1986

\title{
Active Cooling for \\ Downhole Instrumentation: \\ Design Criteria and \\ Conceptual Design Summary
}

Gloria A. Bennett

५OS $\Delta \sqrt{\mathrm{a}} \mathrm{n}(\mathrm{S}$ Los Alamos National Laboratory 
This work was supported by the U.S. Department of Energy, Division of Geothermal and Hydropower Technologies.

\section{Edited by Marge Wilson, ESS Division}

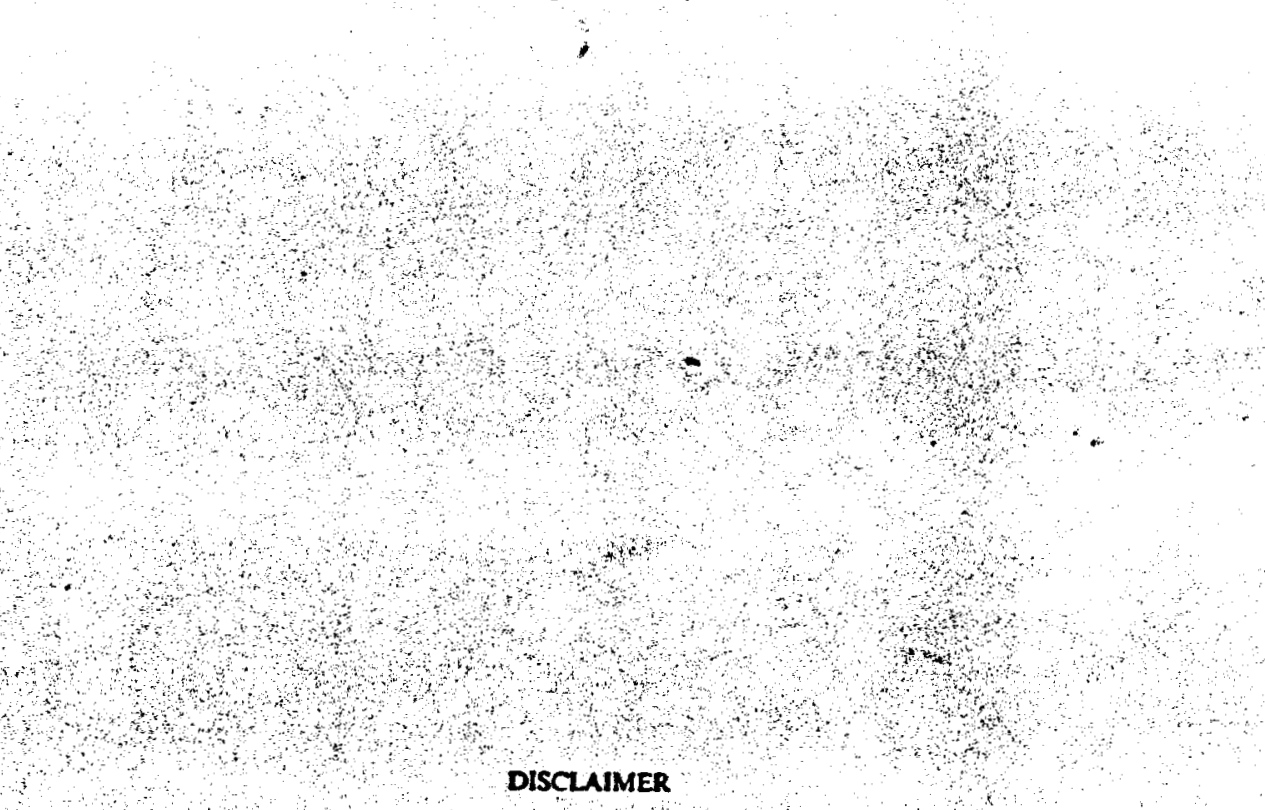

This report was prepared as en eccount of work sponsored by an agency of the Uatied States Co vernment. Neither the Uaited States Government hor any agency thereof, nor any of their employees, makes any

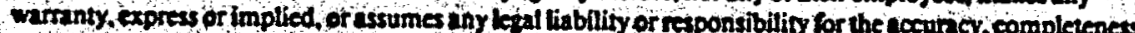
prusefulaess of any falormation, pparatus, product, or procens disclosed of represents thit its use would

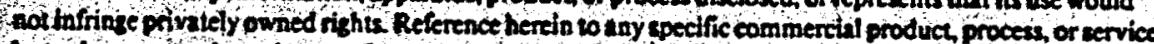

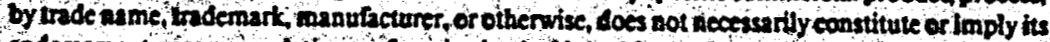

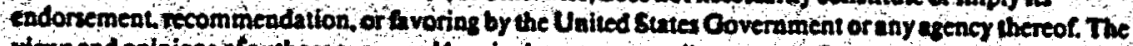
views and oplinions of authars expressed herein do not neccasarily state or hellect those of the Unined Sute Government ar noy esency thene of. 


\section{DISCLAIMER}

This report was prepared as an account of work sponsored by an agency of the United States Government. Neither the United States Government nor any agency Thereof, nor any of their employees, makes any warranty, express or implied, or assumes any legal liability or responsibility for the accuracy, completeness, or usefulness of any information, apparatus, product, or process disclosed, or represents that its use would not infringe privately owned rights. Reference herein to any specific commercial product, process, or service by trade name, trademark, manufacturer, or otherwise does not necessarily constitute or imply its endorsement, recommendation, or favoring by the United States Government or any agency thereof. The views and opinions of authors expressed herein do not necessarily state or reflect those of the United States Government or any agency thereof. 


\section{DISCLAIMER}

Portions of this document may be illegible in electronic image products. Images are produced from the best available original document. 
CONTENTS

Page

ABSTRACT............................................ 1

I. INTRODUCTION ...................................... 1

A. Motivation...................................... 1

B. The Engineering Problem.............................. 2

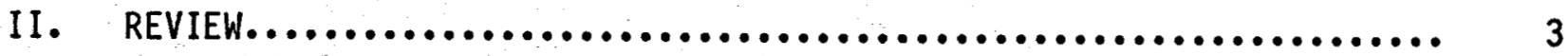

A. Geophysical Instruments and Tools...................... 3

B. Cooling Systems for Geophysical Instruments............... 6

C. Electrical Logging Cables and Cableheads.................. 7

D. High-Temperature Components......................... 7

III. SUMMARY - STATE-OF-THE-ART $\ldots \ldots \ldots \ldots \ldots \ldots \ldots \ldots \ldots \ldots \ldots \ldots \ldots \ldots \ldots \ldots . \ldots$

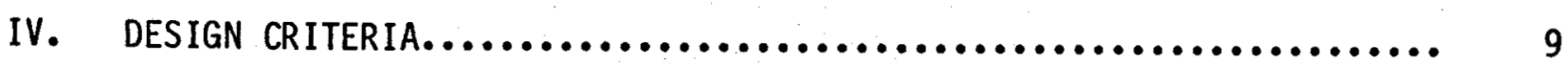

A. Environment .................................... 9

B. Physical Constraints................................ 9

C. Compatibility with Current Systems..................... 9

D. Thermal and Mechanical Loads........................... 10

E. Summary of Imposed Conditions........................ 12

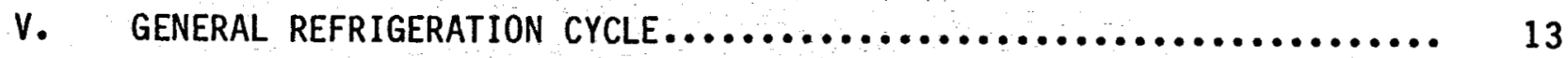

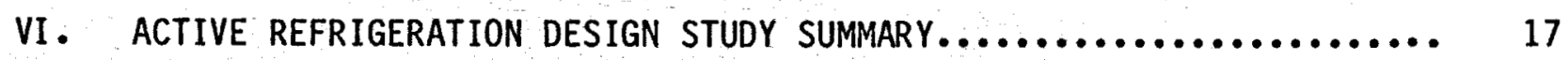

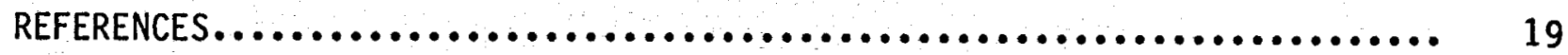


ACTIVE COOLING FOR DOWNHOLE INSTRUMENTATION:

DESIGN CRITERIA AND CONCEPTUAL DESIGN SUMMARY

by

Gloria A. Bennett

\begin{abstract}
This report summarizes the results of a literature survey that describes successful tests of geophysical instruments and their thermal protection systems. The conditions to which an instrument is subjected are formulated into relevant thermal and mechanical design criteria that have proved useful for improving passive thermal protection systems and selecting the preliminary feasibility of active refrigeration systems. A brief summary of the results of a series of conceptual designs on seven different active refrigeration systems is given. The systems are ranked according to feasibility for use in downhole active cooling applications.
\end{abstract}

I. INTRODUCTION

A. Motivation

The development of the geothermal energy resource depends in part on successfully developing cost-effective techniques for creating and enlarging geothermal reservoirs, workable methods for extracting the stored energy, and accurate physical models for predicting reservoir behavior. Each of these endeavors requires extensive data about borehole flow rate, temperature, 
pressure, fluid chemistry, and their associated changes. Acoustic signals at various depths in and between wells provide valuable geophysical information about a particular wellbore and are the basis for mapping fractures and tracking reservoir growth.

The sensors and downhole electronics used in geophysical instruments must withstand the conditions in hot geothermal wellbores to which they are repeatedly subjected. The purpose of this report is to describe current technology in the thermal survival or protection of geophysical tools and instruments, to develop relevant thermal and mechanical design criteria, and to sumarize the results of a series of conceptual designs done on active refrigeration systems to evaluate their feasibility for use in downhole applications.

\section{B. The Engineering Problem}

Conditions in geothermal wells are generally more hostile than in commercial oil or gas wells. High geothermal gradients result in temperatures as high as $320^{\circ} \mathrm{C}$ at depths of $4600 \mathrm{~m}(15000 \mathrm{ft})$. Hydrostatic pressure at that depth and temperature is approximately $38.5 \times 10^{+6} \mathrm{~Pa}(5200 \mathrm{psi})$. Water or geofluid chemistry composition ranges from acidic salt brines to very alkaline solutions, with suspended solids averaging $2000 \mathrm{ppm}^{1}{ }^{1}$ Wellbores in geothermal reservoirs are purposely inclined from vertical and left uncased in their lower sections, which are in naturally heated, unmelted crustal rock such as granite. ${ }^{1}$

These conditions require that instruments be packaged in a pressure vessel, or a sonde, that withstands both high temperature and pressure and the severe abrasion and mechanical vibrations and impacts caused by being dragged across hundreds of feet of rough, exposed granite. Electronics and sensors housed in the sonde must be thermally resistant or be thermally protected to survive exposure at elevated temperatures during experiments over extended periods in hot wells.

Typically, difficulties with current technology instruments and tools arise when measurements are required at temperatures in excess of $200^{\circ} \mathrm{C} .2,3,4,5$. This occurs in the Fenton Hill System (FHS) wells at depths below $3000 \mathrm{~m}$. The wells that make up the FHS have been developed by the Los Alamos National Laboratory to conduct research on reservoir behavior and 
high-temperature instrument development. Thermal survival of commercial tools with ordinary electronics and current technology thermal protection is typically 2-1/2 hours or a single trip into and out of a $3400-\mathrm{m}$ well (11 250 $\mathrm{ft}$ at $150 \mathrm{ft} / \mathrm{min})$. Because the FHS wells are much deeper, 4600 and $4100 \mathrm{~m}$, their bottom-hole temperatures are much higher, and tool thermal survival becomes increasingly less probable. ${ }^{4}$ Development of an active refrigeration system for downhole electronics and sensors would considerably extend the capabilities for measuring geophysical quantities useful for the development and analysis of geothermal resources.

\section{REVIEW}

A survey of the literature in the area of downhole geophysical instruments reveals that information about and expertise in the field is concentrated in private industrial corporations and the national laboratories pursuing research in geophysics, geological engineering, or geothermal energy. ${ }^{5,6}$ Private manufacturers advertise their instrument's capabilities but are not willing to provide information about the tool's construction or design because of its proprietary nature. Thus, results of the research in this area are published only if it is being done by a university or an agency that is subject to the Freedom of Information Act or after the work becomes current technology.

\section{A. Geophysical Instruments and Tools}

Geophysical instruments range in complexity from simple mechanical tools to instruments that have complex moving parts and/or delicate electronics. They can be divided into three broad categories: (1) purely mechanical instruments, (2) instruments with minimal electronics or temperature-hardened sensors, and (3) instruments with complex mechanical components and/or delicate electronics that require mechanical and thermal protection.

Tools in the first category do not require thermal protection. Typical examples of these tools are temperature probes and Kuster gages. Tools in the second category are mechanically simple and typically survive a single trip into and out of a hot wellbore. The thermal capacitance of the tool body provides a major proportion of its thermal protection. These instruments would benefit from a series of analyses to select design improvements in 
insulation materials and their arrangement around the sensors or electronics. Typical examples of these instruments are pressure probes, spinner tools, and the whole array of acoustic-listening instruments. Tools in the third category are mechanically complex inside or outside the sonde. The variable being measured might require extensive delicate electronics that must be thermally protected by a hot service dewar and heat sink. Typical examples of these instruments are caliper tools, FM or multiplexed acoustic instruments, gama tools, and gravity meters.

The following paragraphs contain a brief summary of geophysical instruments and tools that are used in geothermal wellbores. The list is arranged in order of increasing maximum tested survival temperatures. It does not include commercial tools advertised for high temperature that have not been tested at the Los Alamos FHS wells.

The Los Alamos National Laboratory, in cooperation with the Simplec Manufacturing Company, designed and built a low-frequency (magnetostrictive) acoustic source and receiver, which has been tested to $150^{\circ} \mathrm{C} .^{7}$ This instrument contains considerable electronics packaged in a hot service dewar with a passive, phase change, thermal protection system. A flux gate magnetometer produced by Humphrey, Inc., was combined with an inclinometer in an instrument designed by Los Alamos National Laboratory for guiding directional drilling and for borehole surveys. Commercial directional drilling and orientation tools are marketed by the E-W DOT and SS Hadies companies for use at $180^{\circ} \mathrm{C} .{ }^{7}$

A high-temperature, three-axis, downhole geophone system was developed at Los Alamos National Laboratory for mapping hydraulic fractures. A similar acoustic instrument using accelerometers was developed to measure acoustic signals produced during hydraulic fracturing when parked in the inclined portion of a wellbore. Both instruments have dewared electronics and passive thermal protection systems that have been successfully used at $200^{\circ} \mathrm{C} .^{7}$

A high-temperature, high-resolution caliper tool with three independent arms was developed at Los Alamos National Laboratory for precise measurements of casing or borehole diameters and for in situ casing inspections. This tool has been successfully tested at $240^{\circ} \mathrm{C}$ in corrosive high-sediment geofluid conditions. ${ }^{7,8}$

A high-temperature borehole fluid sampler was designed by the Los Alamos National Laboratory that takes two separate samples of $270 \mathrm{cc}$ or a single 
780-cc sample. This instrument has been successfully used to sample wellbore fluid at $240^{\circ} \mathrm{C} .8,9$

The Hot Hole Instruments Company advertises a temperature-pressure instrument, a "spinner tool" for measuring fluid velocity in a wellbore, and a high-temperature slimline televiewer. The temperature and spinner tools have been successfully tested at $250^{\circ} \mathrm{C}$, but results are unknown for the televiewer at high temperatures. ${ }^{3}$

A high-temperature borehole televiewer, acoustically driven, is being developed-jointly by the Los Alamos National Laboratory and the Westfalishe Berggewerkschaftskasse (WBK) of West Germany. This instrument is being designed for use at $260^{\circ} \mathrm{C}$ for 5 hours. 10

A series of four high-temperature, shaped-charge, high-explosive tools have been developed at Los Alamos National Laboratory for use at $260^{\circ} \mathrm{C}$. They have been used to a) produce a rubblized bell-shaped cavity in a wellbore needed for sidetrack drilling in hard formations, b) sever a stuck drill pipe, and c) produce starter cracks in a borehole wall. Each of these three tools has a dewared firing unit that uses a capacitive discharge to fire the detonators. 6,11 The fourth tool is capable of producing a single large acoustic signal of known physical location and known energy. ${ }^{12}$

A high-temperature or fluid velocity tool developed by the Los Alamos National Laboratory measures fluid velocities of 12 to $350 \mathrm{ft} / \mathrm{min}$ at pressures up to $138 \times 10^{+6} \mathrm{~Pa}(20000 \mathrm{psi})$. The tool has been successfully used at temperatures of $275^{\circ} \mathrm{C}$ for extended periods. ${ }^{13}$

Scientific Drilling International, in cooperation with the Los Alamos National Laboratory, improved the thermal capability of the "EYE" steering tool for use at $310^{\circ} \mathrm{C}$. This instrument was tested and used in drilling the FHS wells. 7

At temperatures above $330^{\circ} \mathrm{C}$, there are pressure, temperature and caliper tools that operate mechanically and are manufactured by Kuster, Amerada, and Kindy companies.

The Los Alamos National Laboratory and Mauer Engineering Company jointly designed a high-temperature, all metal downhole turbine to provide precise directional control at depths and temperatures up to $330^{\circ} \mathrm{C}$. This tool is driven by the drilling fluid being circulated to remove cuttings from the hole and represents an advance in high-temperature rotary drilling hardware. 3,7 
B. Cooling Systems for Geophysical Instruments

Cooling systems for geophysical instruments and tools vary from "none" to "sophisticated." The purely mechanical instruments require no cooling. The instruments in the second category do not have any specially designed or specifically intended "thermal protection system." Tools in the third category are thermally protected using a current technology passive cooling system.

A typical cooling system is arranged as shown in Fig. 1, with the electronics and a heat sink protected by a hot service dewar. The heat sink, usually filled with a phase change material, is also used as a closure for the dewar even though there must be some provision left for the wiring to pass from the electronics through the heat sink and finally to the cablehead. The heat from the wellbore and heat generated by the electronics must move from the electronics compartment into the heat sink. Available paths include conduction through long, thin mounting rods or conduction through air. It has been shown that the temperature gradient required to transfer heat from electronics to heat sink is too large to be practical ${ }^{14}$ or requires the compartment temperature to remain above its stated survival limit. One of the disadvantages inherent in the use of passive thermal systems is that their heat absorption capacity is volume limited, and the system does not generally reach steady state when parked on station in a well.

Recent improvements in passive protection systems include using heat pipes to improve thermal conductance of the available paths and changing the heat sink material to ice, thereby improving the thermal potential between the electronics and the heat sink. 15

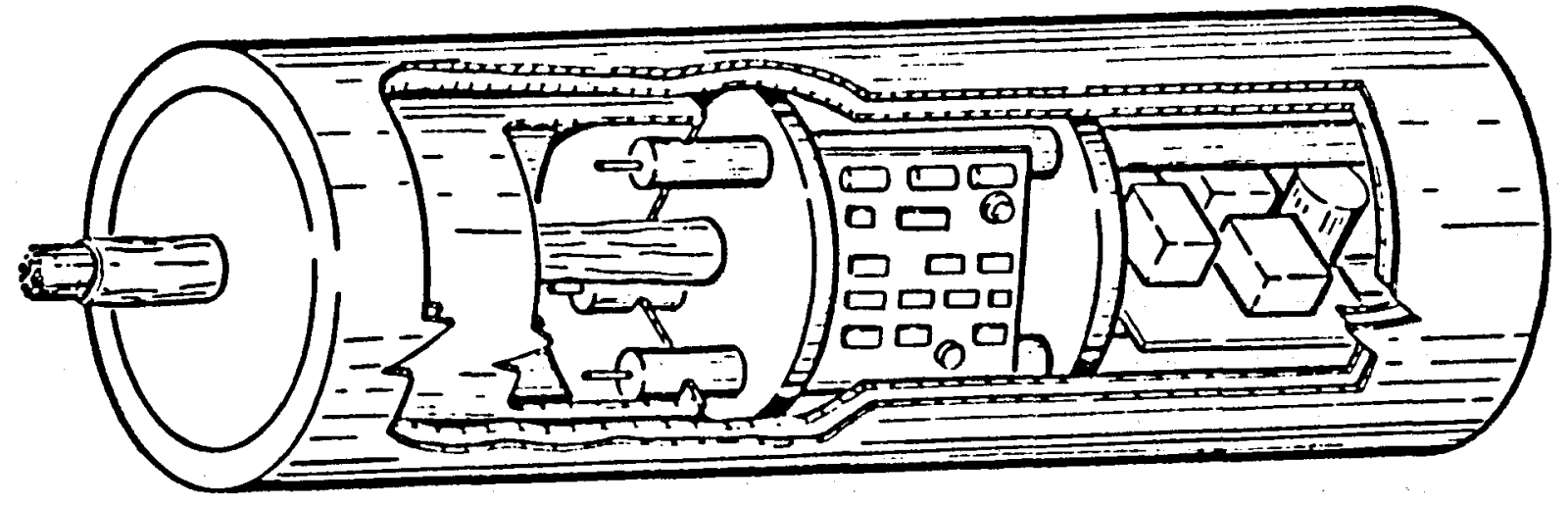

Fig. 1.

Passive thermal protection system. 


\section{Electrical Logging Cables and Cableheads}

Armored electrical logging cables provide the mechanical support for geophysical tools and instruments as well as transmit power and receive signals from downhole instruments. Several manufacturers currently produce single-conductor and multiconductor cable for use in oil and gas well environments. A considerable number of cables have been tested mechanically in hot sour-gas well environments as high as $193^{\circ} \mathrm{C}^{16}$ Coaxial cables from three manufacturers were mechanically and electrically tested by Los Alamos National Laboratory for use at high temperature. ${ }^{1}$

The logging cable is connected to the instrument by a cablehead. The cablehead provides the mechanical transition between a flexible armored cable and the pressure sonde and the electrical transition between thousands of feet of electrical conductors and the electronics package housed in the sonde. The mechanical transition must be designed to provide a watertight seal between wellbore fluid and irregular surface common to armored cables. The cablehead is also the fail-safe disconnect provided in order to retrieve an entire cable when a tool gets stuck in a wellbore. The Los Alamos National Laboratory has designed and tested a high-temperature cablehead that has been used repeatedly at high temperatures and pressures with consistent success. ${ }^{17}$

\section{High-Temperature Components}

There are many components that must survive high temperatures in order for a borehole instrument or tool to function in a geothermal wel1. The most critical components include electric motors to turn valves or advance lead screws, high-temperature elastomer 0 -rings and seals that provide reliable watertight seals, high-temperature connectors that do not degrade significantly when hot, dewars specifically designed for hot service and considerable mechanical abuse, and several high-temperature oils and greases used on threads and internal cavities. Table $I$ lists the components, manufacturers, and highest temperature at which each component has been successfully used. 12

\section{SUMMARY - STATE-OF-THE-ART}

Current research on the development of high-temperature tools is being conducted by several corporations, universities, and national laboratories. 
TABLE I

HIGH-TEMPERATURE COMPONENTS

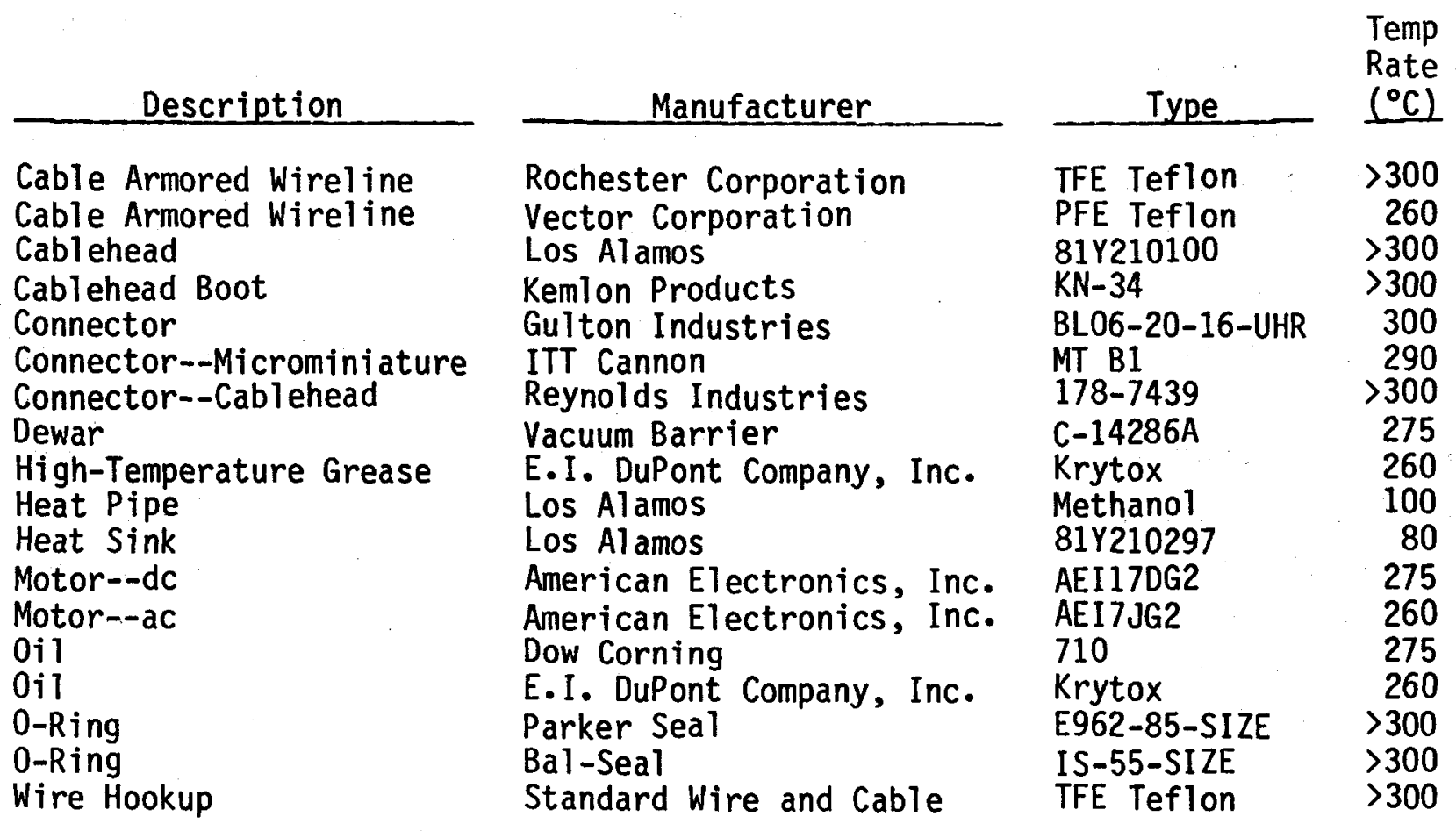

The present available information about commercial high-temperature geophysics tools is limited to advertisements from the tool manufacturers or the logging companies.

Current research on the development of active refrigeration systems in compact geometries that are suitable for use in geophysical instruments is being done by several private corporations and by the Los Alamos National Laboratory. One company has developed a miniature refrigerator for cooling circuit board electronics with milliwatt cooling loads between cryogenic temperatures and ambient conditions. 18,19

There is no currently available information regarding research being done for active refrigeration of multiwatt loads between 150 and $320^{\circ} \mathrm{C}$ in small compact geometries. To the author's knowledge, only the Los Alamos National Laboratory and two private corporations are doing research in this area. Because each firm considers its research proprietary, there is essentially no other information available. 
There exists a specific need for an active refrigeration system developed for the protection of instruments at temperatures in the range of 150 to $320^{\circ} \mathrm{C}$ at multiple watt cooling capacities. Such a system must be small enough to be deployed with an instrument sonde that is parked in a hot well and be efficient enough to be operated using current technology electrical cables or be self-powered. Such a system would make measurements of acoustic, magnetic, nuclear, and other types of data possible in high-temperature wellbores. This advancement would greatly enhance the development of cost-effective techniques for creating and enlarging geothermal reservoirs and improve the accuracy of mathematical reservoir modeling.

\section{DESIGN CRITERIA}

\section{A. Environment}

Geothermal wells are hostile environments because of their high-pressure, high-temperature, corrosive fluid solutions and their highly abrasive borehole walls. The instrument pressure vessels, or sondes, must withstand as much as $82.7 \times 10^{+6} \mathrm{~Pa}(12000 \mathrm{psi})$ at $300^{\circ} \mathrm{C}$ in fluid solutions that average $2000-\mathrm{ppm}$ suspended solids and have a $\mathrm{pH}$ range from 2 to $12 .^{7}$

\section{B. Physical Constraints}

Tool shapes are restricted to small-diameter, long cylinders in order to pass through wellhead hardware and still slide down into a well. Overall length is restricted by the available distance between wellhead hardware, packoffs, valves, etc., and the sheave over which the cable must pass. Tool diameter is restricted by the wellhead diameter or by the casing diameter, whichever is smaller. Because tools must be manually lifted from a trailer or a staging bench, their weight is 1 imited to approximately $300 \mathrm{lb}$. Manual handling must be considered because space around a well head is usually very confined and dependence on an available crane is impractical in remote areas.

\section{Compatibility with Current Systems}

Figure 2 shows a schematic of typical rigging for a downhole data logging experiment. A tool is suspended from the cablehead that provides electrical and mechanical connection from the instrument to the cable and then to the data acquisition system at the surface. The logging cable and the cablehead 


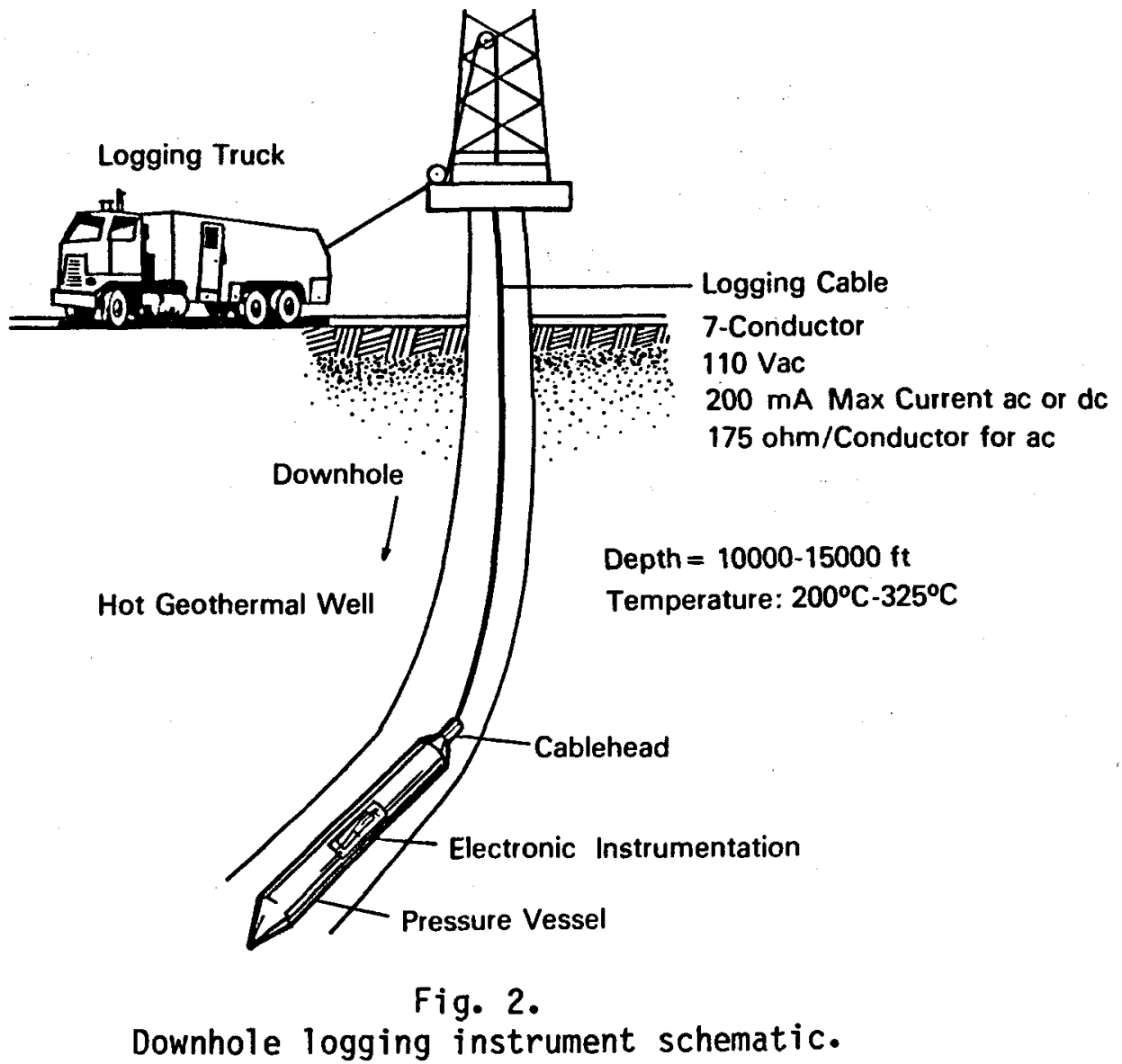

must also survive high temperatures and resist water leakage that causes shorting out between conductors. Signals from the instrument and power for its operation are transmitted through the logging cable. The available cables are typically capable of transmitting $200 \mathrm{~mA}$ at 110 Vac maximum current per conductor.

\section{Thermal and Mechanical Loads}

The proposed system must withstand the mechanical and thermal loads imposed on it during transport to and from the well site, data logging during an experiment, and storage while not in use.

There are no unusual thermal loads imposed during tool transport. The high temperatures in wellbores impose the largest heating load on the tool and its electronics and thermal protection system. The temperature gradient in the FHS wells is shown in Fig. 3,4 and the calculated heat flux at the tool body outer surface for conditions in the FHS wells is shown in Figs. 4 and 5.14 


\section{EE-3 TEMPERATURE LOG}

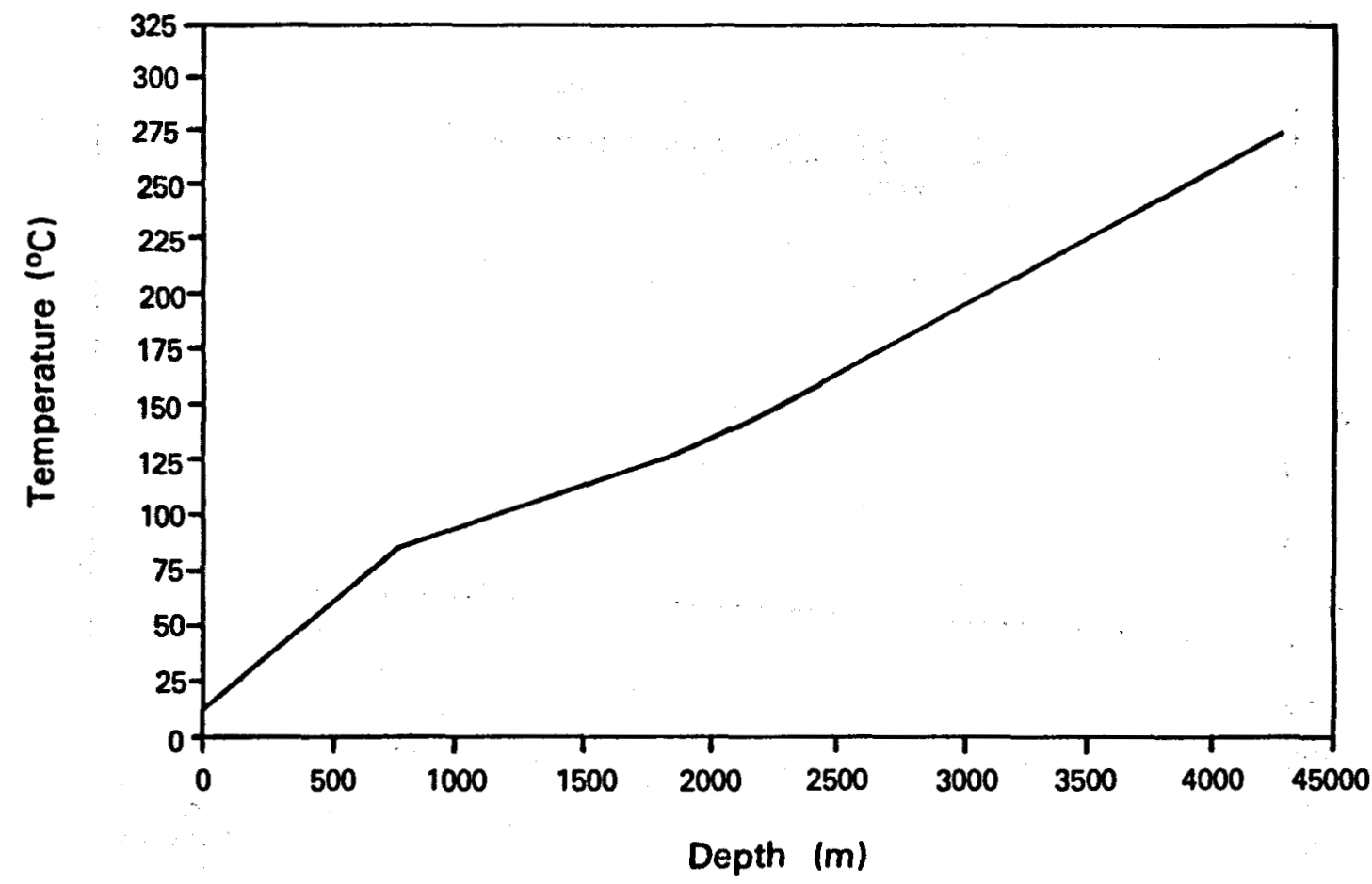

Fig. 3.

Geothermal gradient at Fenton Hiil, New Mexico.

The conditions depicted in Figs. 3-5 represent some of the severest thermal loads to which a thermally delicate instrument might be subjected. This geothermal gradient is one of the steepest published ${ }^{1}$ and produces large temperature differences between the wellbore and the cool interior of an instrument package. The heat flux shown in Fig. 4 is also relatively severe in that it is the result of a high heat transfer coefficient. Each parameter in the Colburn equation is near maximum--the high Reynolds number for a typical fast trip into a well at $0.76 \mathrm{~m} / \mathrm{s}(150 \mathrm{ft} / \mathrm{min})$ and a high Prandtl number for water as opposed to gas or steam. The calculated flux crossing the dewar walls is approximately $36 \mathrm{~W} / \mathrm{m}^{2}$. The heat reaching delicate instruments packaged with $0.20 \mathrm{~m}^{2}$ exposed area is $8 \mathrm{~W}$. This requires that an active refrigeration system be capable of removing $8 \mathrm{~W}$ of heat input from the wellbore, plus self-generated heat, plus the heat of compression supplied to the system and then be able to reject this sum to the wellbore.

The low-temperature thermal loads are imposed during overnight outdoor storage in cold weather. Mechanical components must accommodate thermal 


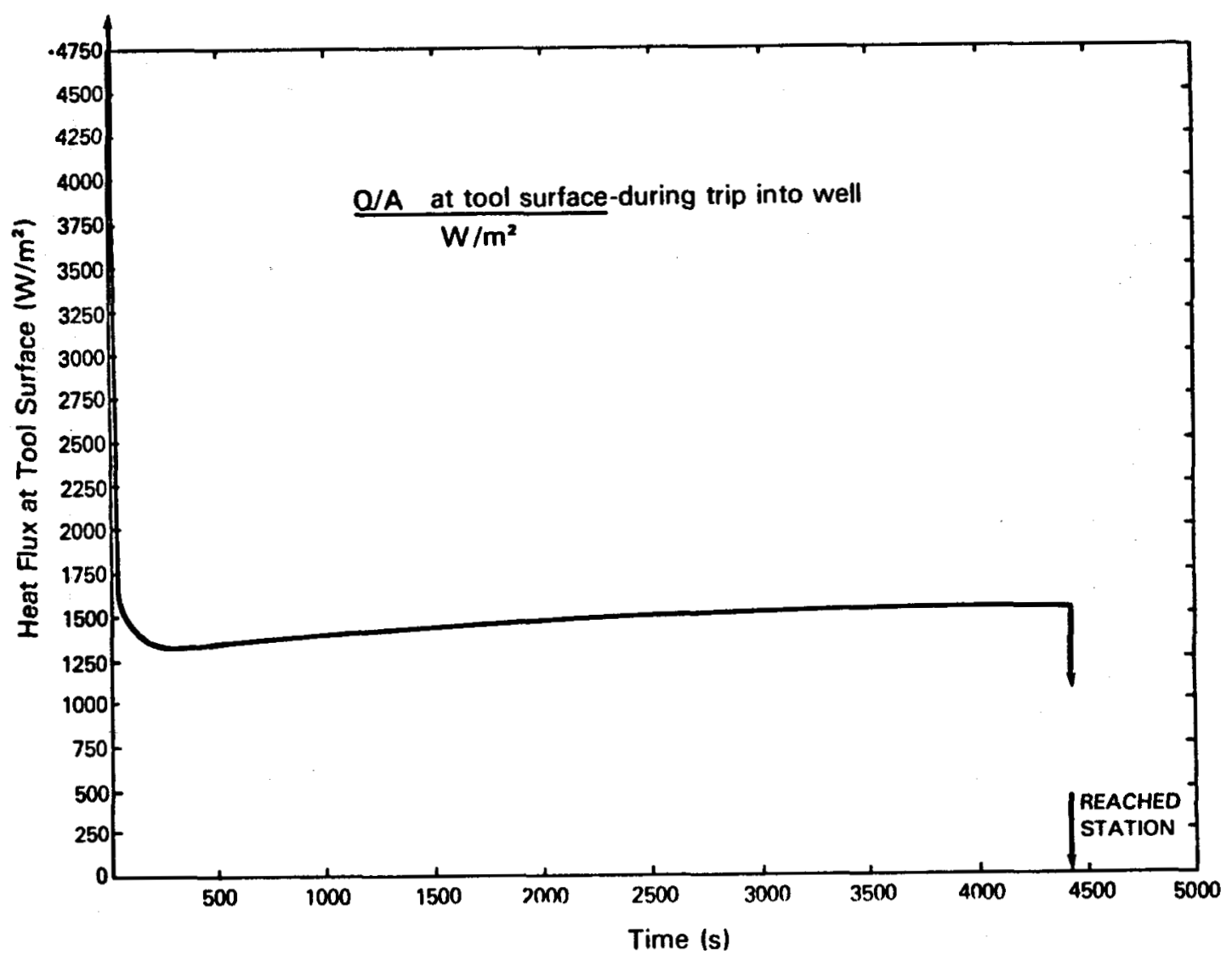

Fig. 4.

Tool-surface heat-flux time history (tripping in).

expansions and contractions caused by temperature swings as large as $350^{\circ} \mathrm{C}$ between night-time lows and bottom-hole temperatures.

Mechanical loads imposed during transport consist mainly of vibration from 10 to $400 \mathrm{~Hz}$ at up to $15 \mathrm{~g}$. Because tools are transported horizontally, radiation shields in dewars must be designed to resist shifting. Cushioning systems for mechanical components of an instrument inside the dewar must resist the horizontal vibration imposed during shipment as well as vibration imposed during vertical trips in and out of a well at velocities averaging $0.762 \mathrm{~m} / \mathrm{s}(150 \mathrm{ft} / \mathrm{min})$. Occasionally a tool is dropped or impacts an obstruction along the wall of the wellbore, causing large momentary forces.

E. Summary of Imposed Conditions

Temperature $0^{\circ} \mathrm{C}<\mathrm{T}<320^{\circ} \mathrm{C}$

Pressure $0 \mathrm{~Pa}<\mathrm{P}<82.7 \times 10+6 \mathrm{~Pa}$ 


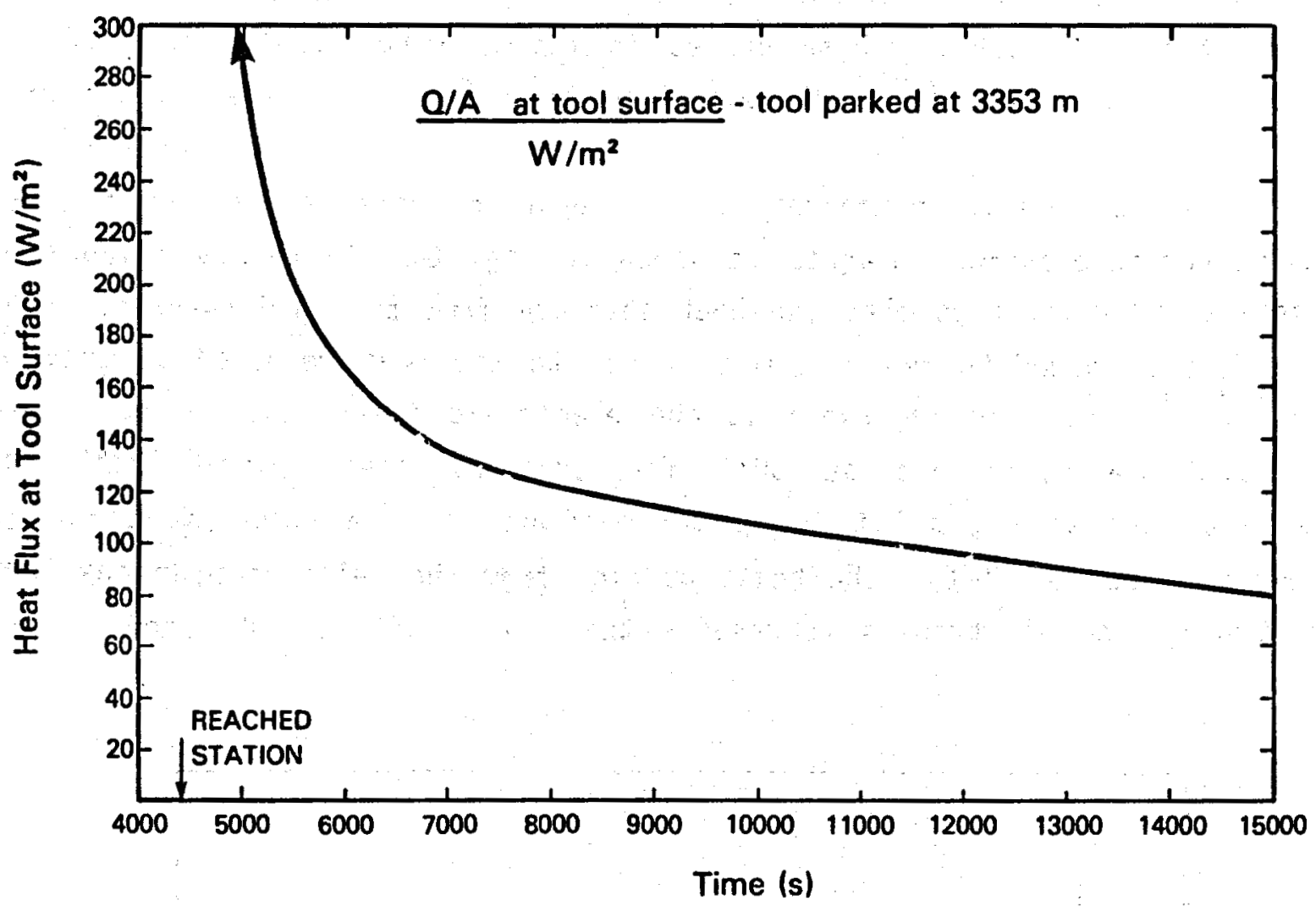

Fig. 5 .

Tool-surface heat-flux time history (parked).

$\begin{array}{ll}\mathrm{pH} & 2<\mathrm{pH}<12 \\ \text { Suspended Solids } & >10000 \mathrm{ppm} \\ \text { Vibration } & 10<\mathrm{Hz}<400 \\ \text { Impact } & \text { up to } 15 \mathrm{~g}\end{array}$

V. GENERAL REFRIGERATION CYCLE

There are numerous cycles by which refrigeration can be achieved. The Carnot cycle is the most commonly studied refrigerator because it is thermodynamically ideal. There are several common refrigeration cycles in practical use, which include the Rankine cycle, Brayton cycle, and absorption refrigeration. Other less familiar or even exotic methods or cycles include thermoelectric refrigerators, magnetocaloric refrigerators, acoustic 
refrigerators, and refrigerators that use changes in chemical composition. The efficiency of each of these cycles is compared to the Carnot cycle to provide a normalized method of comparison from which to make an informed choice.

The simplest ideal thermodynamic refrigeration cycle is the Carnot cycle whose temperature-entropy diagram is shown in Fig. 6 . An energy balance on the refrigerator requires that the heat absorbed from the cold reservoir plus the shaft work added to the system be equal to the heat rejected to the hot reservoir. ${ }^{20}$ The cold reservoir is the electronic instrument package where Tcold must be maintained at $80^{\circ} \mathrm{C}$ for ordinary electronics, $120^{\circ} \mathrm{C}$ for components satisfying military specifications, and in some cases can be allowed to rise to $150^{\circ} \mathrm{C}$. The heat entering from the wellbore plus any heat generated by the electronics represents the amount of heat absorbed by the

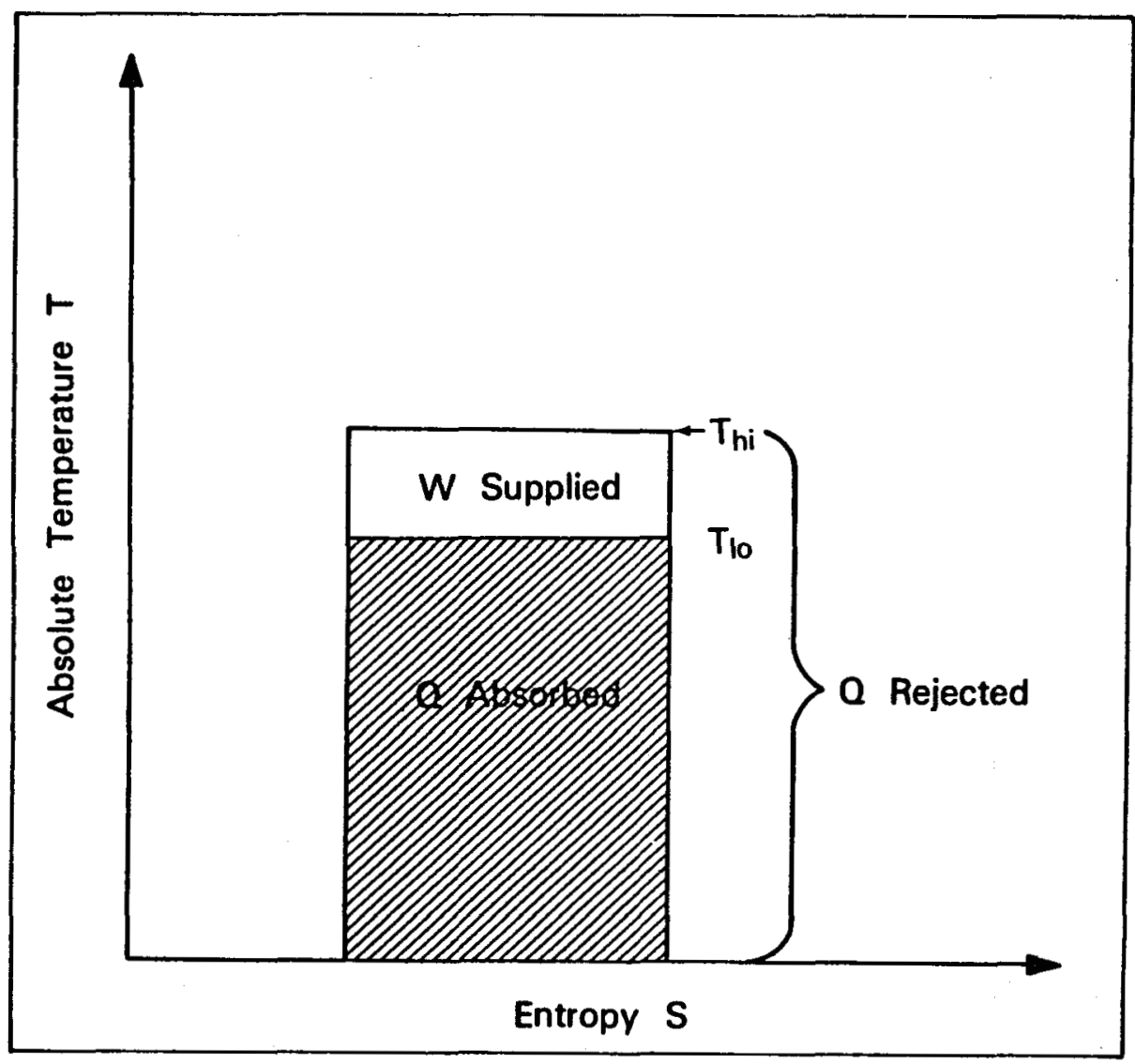

Fig. 6.

Carnot cycle temperature-entropy diagram. 
refrigerator. The Thot reservoir is the hot geothermal wellbore with a temperature gradient as shown in Fig. 3, for which the maximum thot is $320^{\circ} \mathrm{C}$ in the FHS wells.

Heat transfer between the refrigerator and both reservoirs requires a finite temperature difference. This implies that the substance absorbing heat from the electronics must be cooler than Tcold. Then the same substance must undergo some process to raise its temperature to a level higher than the Thot reservoir in order to reject heat to the wellbore. The physical size limits of the tool will dictate the size and shape of the heat transfer areas used for both heat exchange processes and will result in a tradeoff between physical size and approach temperature differences.

Refrigerator efficiency is .generally defined by the coefficient of performance, which is the ratio of heat extracted from the cold reservoir to the work input to the refrigerator or

$$
\mathrm{COP}==\text { Qextracted/Winput. }
$$

The ideal coefficient of performance for a Carnot refrigerator operating with infinitesimal temperature differences between the refrigerant fluid and both heat reservoirs is given by

$$
\text { COP }=T \operatorname{col} d /(\text { Thot }-T \text { cold }) \text {. }
$$

No real refrigeration process approaches this ideal COP because of thermodynamic irreversibilities. Actual COP for real refrigerators varies from $3 \%$ to $40 \%$ of Carnot.

The refrigerator design being proposed must be compatible both mechanically and electrically with currently used equipment. Primarily, it must be small enough to fit inside tool sondes and dewars. Moderately priced hot service dewars in current use at the Los Alamos National Laboratory allow a heat flux of approximately $36 \mathrm{~W} / \mathrm{m}^{2}$ to reach the instrumentation being protected. ${ }^{13}$ An electronic instrument packaged with $0.2 \mathrm{~m}^{2}$ exposed area receives $8 \mathrm{~W}$ from the wellbore. The actual work input required to remove this amount of heat depends on the actual COP for a particular system and is given by

Wactual = Qextracted/COPactual.

Table II shows a matrix of possible choices for cold reservoir and hot reservoir temperatures with their associated ideal coefficient of performance. It also lists COP for actual refrigerators shown as percentage of the ideal COP. Table III shows a matrix of input power demands for each case. If power 


\section{TABLE II}

COEFFICIENTS OF PERFORMANCE

Cold Reservoir

$\begin{array}{ll}\text { Hot Reservoir } & \text { Ideal } \\ T_{\text {hi }}=220^{\circ} \mathrm{C} & 10 \% \\ & 20 \% \\ & 30 \%\end{array}$

Hot Reservoir Ideal

$T_{\text {hi }}=270^{\circ} \mathrm{C} \quad 10 \%$
$20 \%$

$30 \%$

Hot Reservoir Ideal

$\mathrm{T}_{\text {hi }}=320^{\circ} \mathrm{C} \quad 10 \%$

$20 \%$

$30 \%$
$T_{10}$

$80^{\circ} \mathrm{C}$

2.52

0.252

0.504

0.756

1.858

0.186

0.372

0.557

1.471

0.147

0.294

0.441
$\mathrm{T}_{10}$

$\underline{115^{\circ} \mathrm{C}}$

3.69

0.369

0.739

1.108

2.503

0.250

0.500

0.751

1.892

0.189

0.378

0.567
$\mathrm{T}_{10}$

$150^{\circ} \mathrm{C}$

6.04

0.604

1.21

1.81

3.525

0.352

0.704

1.056

2.488

0.248

0.497

0.745

TABLE III

INPUT POWER DEMANDS (W)

\section{Cold Reservoir \\ Hot Reservoir Ideal \\ $\begin{array}{ll}T_{\text {hi }}=220^{\circ} \mathrm{C} & 10 \% \\ & 20 \%\end{array}$ \\ $30 \%$}

Hot Reservoir Ideal

$T_{h i}=270^{\circ} \mathrm{C} \quad 10 \%$

$30 \%$

Hot Reservoir Ideal

$\mathrm{T}_{\mathrm{hi}}=320^{\circ} \mathrm{C} \quad 10 \%$

$20 \%$
$\mathrm{T}_{10}$

$80^{\circ} \mathrm{C}$

3.17

31.7

15.87

10.58

4.31

43.1

21.5

14.4

5.44

54.4

27.2

18.1
$\mathrm{T}_{10}$

$115^{\circ} \mathrm{C}$

2.16

21.6

10.8

7.22

3.19

31.9

16.0

10.6

4.22

42.2

21.1

14.1
$\mathrm{T}_{10}$ $150^{\circ} \mathrm{C}$

1.32

13.33

6.67

4.41

2.27

22.7

11.4

7.57

3.21

32.1

16.1

10.7

Available Power Input -- 110 Vac $\times 0.200 a=22 \mathrm{~W}$ 
input is limited, then Table III provides an array of design choices. If the design criteria have fixed the reservoir temperature, which is the case for this work, then the level at which an actual refrigerator must operate is defined. Because available power input through a single conductor is limited to $22 \mathrm{~W}$, only the cases for which power is less than or equal to $22 \mathrm{~W}$ are considered.

This choice of maximum input power is amenable for use with multiconductor cables that are used to deploy instruments that do not use all the conductors for transmitting analog signals between electronics and data acquisition systems. The power limit is also compatible with single-conductor or coaxial cables that are used to deploy instruments containing FM or PCM signals that can be transmitted over the same conductors used to provide power downhole.

The refrigeration theory for each system was studied in enough detail (a) to determine whether the theory was still in the research stage or could be applied to the assumed reservoir conditions and heat loads and (b) to locate or determine appropriate refrigerants. A conceptual design, or in some cases a series of designs, was made for each system for which an appropriate refrigerant was available. A preliminary analysis of each design was carried out that included the relevant engineering parameters. The analysis provided sizes of individual components of each refrigerator and provided data from which to chose the best refrigerant for a given system.

\section{ACTIVE REFRIGERATION DESIGN STUDY SUMMARY}

Table IV shows the listing of refrigeration cycles arranged in order of decreasing coefficient of performance (COP) for an estimated actual refrigerator. The efficiency of each component in a cycle was chosen from data in the literature or is a guess based on similar components.

The two-stage Rankine cycle, using water in the first stage and thermex in the second stage, resulted in the highest COP. This refrigerator would require two compressors, three heat exchangers, and two expansion valves. The major disadvantage of this system is that fluid leakage from the refrigerator would lead to electrical failure and probable damage to electronics.

The Brayton cycle using a mixture of helium and xenon as the refrigerant is the next most efficient refrigerator. This cycle would require only a 
TABLE IV

REFRIGERATOR FEASIBILITY RANKING

\section{Refrigerator}

1) Two-stage Rankine

2) Brayton w/turbine

3) Acoustic

4) Brayton w/valve

5) Cascaded thermoelectric

6) Magnetocal oric

7) Fuel cells

8) Absorption

Refrigerant

$\mathrm{H}_{2} \mathrm{O}$ and thermex

Xenon/hel ium

Helium

Xenon/hel ium

$\mathrm{Bi}_{2} \mathrm{Te}_{3}-\mathrm{PbTe}$
Sodium

None
Remarks

Refrigerant leakage causes electrical failure.

Mechanically intricate.

Requires high-performance heat exchangers.

Requires twice the available power. Simpler design than 2).

Requires five times the available power. No moving parts or flowing fluids.

Three refrigerants available for specific small $\Delta T$.

Fuel cell in research stages.

No suitable refrigerant found.

single stage, or one compressor, two heat exchangers, and a turbine. The acoustic refrigerator using helium as a refrigerant shows nearly the same COP. In both of the above cases, refrigerant leakage would cause a graceful degradation of both the refrigerator and electronics operation. The acoustic refrigerator is a simpler mechanical design with less tubing but requires heat exchangers to operate dynamically rather than at steady-state conditions.

The above cycles are all feasible since their COP are above $15 \%$ of Carnot and require less than $22 \mathrm{~W}$ of input power. The remaining refrigerator designs resulted in COP less than $15 \%$ of Carnot or did not have suitable refrigerants.

The refrigerator using a Brayton cycle with a valve in place of a turbine is marginally unfeasible because it requires two times the available power input. Possible application might be considered if more than one conductor is available for power input, such as multiplexed application on a multiconductor wireline. This cycle is much less mechanically intricate and probably more reliable. 
The thermoelectric refrigerators evaluated are all unfeasible for the stated application, requiring at least five times the stated maximum power input. These methods might be considered feasible for use with smaller $\Delta T$ between reservoirs such as $150-220^{\circ} \mathrm{C}$ at the stated cooling loads.

The magnetocaloric refrigerator is suited for removal of larger heat loads over a very small reservoir temperature difference. It might be useful for long-term cooling application at several specific temperatures.

The only suitable fuel cells found for use in a regenerative fuel cell cycle was the thermally regenerative electrochemical system (TRES) fuel cell using sodium as the electro-active fluid. It is in the laboratory development stages. There was no suitable refrigerant found for an absorption refrigerator.

\section{REFERENCES}

1. M. C. Smith and G. M. Ponder, Eds., "Hot Dry Rock Geothermal Energy Development Program - Annual Report Fiscal Year 1981," Los Alamos National Laboratory report LA-9287-HDR (Apri1 1982).

2. M. D. Lamers, "Measurement Requirements and Methods for Geothermal Reservoir System Parameters," Measurement Analysis Corporation report 7806-01, LBL-9090 (August 1979).

3. C. Helmick, S. Koczan, and R. Pettitt, Eds., "Planning and Drilling Energy Extraction Hole EE-2 - A Precisely Oriented and Deviated Hole in Hot Granitic Rock," LOS Alamos National Laboratory report LA-9302-HDR (April 1982).

4. J. C. Rowley and R. S. Carden, "Drilling of Hot Dry Rock Geothermal Energy Extraction Well EE-3," Los Alamos National Laboratory report LA-9512-HDR (August 1982).

5. R. K. Traeger, "Geoscience Experiments in Boreholes: Instrumentation," in Observation of the Continental Crust Through Drilling, (Springer-Verlag, Berlin Heidelberg, 1985).

6. B. R. Dennis, "Logging Technology for High-Temperature Geothermal Boreholes," in Observation of the Continental Crust Through Drilling, (Springer-Verlag, Berlin Heidelberg, 1985).

7. M. C. Smith, "Major Accomplishments of the Hot Dry Rock Program 1970-1982," Los Alamos National Laboratory report LALP-82-37 (August 1983).

8. B. R. Dennis, "High-Temperature Well-Logging Instrumentation Proceedings," Los Alamos, NM, November 13-14,. 1985 (Los Alamos National Laboratory). 
9. J. Archuleta, C. Fink, J. Kurtenbach, "Equipment Development Report, Borehole Fluid Sampling Tool," Los Alamos Scientific Laboratory report LA-7152-MS (February 1978).

10. T. K. Moore, K. Hinz, and J. Archuleta, "Development of a New Borehole Acoustic Televiewer for Geothermal Applications," 1985 International Symposium on Geothermal Energy, Vol. II (Geothermal Resources Council, Davis, California, 1985).

11. S. P. Koczan, W. W. Patterson, and R. H. Rochester, "Drill-Pipe Severing Tool with High-Temperature Explosives," Los Alamos National Laboratory report LA-9483-MS (August 1982).

12. B. R. Dennis, S. P. Koczan, and E. L. Stephani, "High-Temperature Borehole Instrumentation," Los Alamos National Laboratory report LA-10558-HDR (October 1985).

13. R. Lawton, J. Kolar, and B. Todd, "Fluid Velocity Sensor Development Report," Los Alamos National Laboratory report LALP-82-16 (September 1982).

14. G. A. Bennett and G. R. Sherman, "Analysis and Thermal Design Improvements of Downhole Tools for Use in Hot Dry Wells," Los Alamos National Laboratory report LA-9671-HDR (February 1983).

15. G. A. Bennett, "Upgrades in Thermal Protection for Downhole Instruments," 1985 International Symposium on Geothermal Energy, Vol. II (Geothermal Resources Council, Davis, California, 1985).

16. G. A. Vaugh and H. E. Chaung, "Wireline Materials for Sour Service," International Corrosion Forum, Ontario, Canada, Paper 182 (April 1981).

17. J. Archuleta and B. Todd, "Hot Dry Rock Geothermal Energy Development Project, Cablehead Assembly, Equipment Development Report," Los Alamos Scientific Laboratory report LA-7325-MS (August 1978).

18. R. Brandt, M. Nisenoff and E. Edel sack, "Programs on Superconducting Materials and Miniature Cryocoolers in the United States," Superconductor Materials Science; Metallurgy Fabrication and Applications (Plenum Press, New York, 1981).

19. W. A. Little, "Microminiature Refrigeration - Small is Better," Physics, Vols. 109 and 110B (North-Holl and Publishing Company, New York, 1982).

20. B. V. Karlekar, Thermodynamics for Engineers (Prentice-Hall, Inc., Englewood Cliffs, 1983). 